\title{
Analysis of Translation Strategy in Transferring meaning of English Idiom into Bahasa Indonesia in the subtitle of Pitch Perfect 3 Movie
}

\author{
Monicha Destaria, Yulan Puspita Rini \\ UIN Raden Intan Lampung \\ Email: destariamonik@gmail.com
}

\begin{abstract}
Transferring meaning embedded by English idiom is not an easy way to do. The meaning contained by English Idiom cannot be comprehended by merely knowing the meaning from each word arranging the idiom. Dealing with English idiom in translation is quite hard because the translator has to transfer the meaning of English idiom into Bahasa Indonesia rightly. On the other hand, it is quite difficult to find the equivalence term in Bahasa Indonesia reflecting the same meaning as it is reflected in the source text. To manage this problem, the translation strategies need to be applied. This research focuses on analyzing the translation strategies used by the translator in transferring the meaning of English idioms into Bahasa Indonesia in the subtitle of Pitch Perfect 3 Movie. The research method is descriptive qualitative method.. Baker's translation strategies is used as guideline in classifying the translation strategies used. After finding the type of translation strategies employed, further identifying whether the meaning of English idiom is transferred rightly in Bahasa Indonesia. According to the finding, translation by using idiom in similar meaning and disimilar form was not used by the translator to translate the idioms. The frequency of translation by using idiom in similar meaning but disimilar form strategy is 4 idioms. 46 idioms were translated by using paraphrased strategy. It is only 1 idiom was translated by using omission strategy. that the meaning of 36 idioms are transferred accurately. The meaning of four idioms were transferred Less-accurately. The meaning of 11 idioms were classified as inaccurate translation.
\end{abstract}

Key words: $\quad$ accuracy, idiom, meaning, translation strategy 


\section{A. INTRODUCTION}

Translation is the communication of meaning frome one language (the source) to another language (the target). In the process of doing translation, the first step that must be done by translator is finding the meaning of source text. Grasping the meaning has to consider many things such as context, grammar, social culture, etc. It is done to get the right meaning reflected by the expression in the source text. One of the most difficult terms to be translated is idiom since the meaning of idiom cannot be rendered literally. According to Larson, idiom is a string of words whose meaning is different from the meaning conveyed by the individual words (Larson, 1998: 23). It can be concluded that the meaning of idioms cannot be comprehended by drawing from the meaning of words establishing the idiom literally. It will pose problem when the translator doesn't aware the meaning embedded by the idiom. As the consequence, the translator renders the wrong meaning and it will influence the result of the translation.

Further, Baker gives detailed explanation about the difficulties in translating idioms. They are 1) An idiom may have no equivalent in the target language. 2) An idiom may have a similar counterpart in the target language, but its context of use maybe different. 3) An idiom may be used in the source text in both its literal and idiomatic senses at the same time. Unless the target language idiom corresponds to the source language idiom both in form and in meaning, the play on idiom cannot be succesfully reproduced in the target text. 4) The convention of using idioms in written discourse, the contexts in which they can be used, and their frequency of use may be different in the source and target language (Baker, 2006: 68-70). Previous discussion shows that interpreting the meaning of idiom is not easy. After finding the right meaning of idiom, the translator has to pay 
attention to the context and convention of the idiom use and find the equivalence in target language.

Because there are several difficulties in translating idioms, the translator needs translation strategies that the meaning of idiom in the source text can be managed well in the target text. The translation strategy is used to help the translators in translating idioms. Baker states that in order to transfer the messages of idioms to be translated accurately and efficiently, the translator must choose the most appropriate strategy ( 2006: 72).

Further, Baker classifies the translation strategy into four strategies. The first is using an idiom of similar meaning and form. It means that employing idiom in the target language which conveys roughly the same meaning as that of the source language idiom and consists of equivalent lexical items. Second, using an idiom of similar meaning but dissimilar form. The translator is allowed to translate idiom by using the different lexical items as long as the meaning expressed the same. Third, translation by Paraphrase. This way can be used when a match of idiom cannot be found in the target language or when it seems inappropriate to use idiomatic language in the target text because of differences in stylistics preferences of the source and target languages. The last, translation by Omission. This is used when the meaning of idiom in the source language has no close match in the target language, and its meaning cannot be easily paraphrased (Baker, 2006: 71-77). Theory proposed by Baker about translation strategies that can be applied in transferring meaning of Idiom from source language into target language will be the underlying theory in doing analysis in this research.

This research deals with translation of English idiom into Bahasa Indonesia. In Pitch Perfect 3 movie, there are many idioms employed within the conversation. This movie is viewed by many teenagers in Indonesia. They watch the movie by 
seeing the subtitle that has been translated into Bahasa Indonesia. Instead of having fun, one of their purposes in watching this movie is to learn English through movie. They regard this as a fun way. While listening to the English conversation, the viewers will see the Indonesian subtitle that they can comprehend the meaning. In this case, they learn English through audio and visual. Indonesian subtitle helps them in understanding idea spoken by characters. Since there are many idioms in this movie, it is important to handle the meaning by employing appropriate translation strategies that it finds the equivalence term in Bahasa Indonesia. This research analyzes the translation strategies used in transferring the meaning of idiom in English subtitle into Indonesian subtitle. Then, it is analyzed whether the meaning of idioms can be conveyed rightly in target text. It is expected that the result of the research can accommodate the difficulty of translating English idiom into Bahasa Indonesia.

\section{B. RESEARCH METHOD}

This research used descriptive qualitative research which is defined as a research of which the data in the form of written or oral words that is descriptively analyzed. This research is indeed supposed to be qualitative, because the data in qualitative research are collected in the form of words or pictures rather than numbers (Fraenkel \& Wallen, 2010: 423). It means that the data of this research were presented by the detailed explanation of the result of analysis. It is supported by Moleong who states that in descriptive qualitative research, the writer tends to prior in accurate explanation to analyze and present what will find" (2003: 6).

To obtain the required data, content analysis is applied. Leedy and Ormrod in Williams state that content analysis is a detailed and systematic examination of the contents of a particular body of materials for the purpose of identifying 
patterns, themes, or biases (2007: 53). This method reviews forms of human communication including books, newspapers, films/movies, etc. Since the data of this study is English idioms translated into Bahasa Indonesia, this is considered appropriate for the aims and the nature of the study. The research instrument of research was the researcher itself. It is stated that in qualitative research the researcher is the key instrument (Sugiyono, 2008: 222). The subject of the research was Pitch Perfect 3 movie.

While the data was gathered, the data were examined closely to determine the translation strategy applied. The data was classified based on Baker's translation strategies. After that, examining whether the meaning of English idioms was conveyed well in Bahasa Indonesia.

\section{FINDINGS AND DISCUSSION}

\section{Findings}

After doing the analysis, 51 idioms were found from the movie. From the analysis, it can be seen that the idioms were translated by using three strategies out of four strategies proposed by Baker. Most of all the meaning of the English idiom can be transferred accurately in Bahasa Indonesia. On the other hand, There are several of them that were classified as less accurate, or not accurate translation. The finding of this research are shown below.

\section{Translation Strategies}

According to the analysis, 51 idioms were translated by using translation strategies provided by Baker (Baker 2006). The table below shows the frequency of translation strategies used to translate idiom in the Pitch Perfect 3 Movie.

Table 1. Table The Frequency of Translation Strategies Used

\begin{tabular}{|c|c|c|}
\hline No & Translation Strategy & Frequency \\
\hline
\end{tabular}




\begin{tabular}{|c|l|c|}
\hline 1 & $\begin{array}{l}\text { Translation by Using Idiom in Similar Meaning and } \\
\text { Similar Form }\end{array}$ & 0 \\
\hline 2 & $\begin{array}{l}\text { Translation by Using Idiom in Similar Meaning but } \\
\text { Disimilar Form }\end{array}$ & 4 \\
\hline 3 & Translation by Paraphrases & 46 \\
\hline 4 & Translation by Omission & 1 \\
\hline
\end{tabular}

From the table above, it can be seen that there are four strategies provided by Baker. According to the table, translation by using idiom in similar meaning and disimilar form was not used by the translator to translate the idioms. The frequency of translation by using idiom in similar meaning but disimilar form strategy is 4 idioms. 46 idioms were translated by using paraphrased strategy. It is only 1 idiom was translated by using omission strategy.

\section{Meaning Equivalence}

After doing the analysis, the researcher found that there are some meaning of the idioms that were translated correctly and translated uncorrectly. The following table describes the distribution of the meaning equivalence in the target text.

Table 2. The Frequency of Equivalence Translation

\begin{tabular}{|c|c|c|}
\hline No & Equivalence Level & Frequency \\
\hline 1 & Accurate & 36 \\
\hline 2 & Less-accurate & 4 \\
\hline 3 & Inaccurate & 11 \\
\hline
\end{tabular}

From the table above, it can be concluded that the meaning of 36 idioms are transferred accurately. The meaning of four idioms were transferred Lessaccurately. The meaning of 11 idioms were classified as inaccurate translation. The following table summarizes the strategy used in transferring the meaning and the analysis of meaning equivalence. 
Table 3. Table of Translation Stragey used and the Equivalence Level Frequency

\begin{tabular}{|c|l|c|c|c|}
\hline \multirow{2}{*}{ No } & \multicolumn{1}{|c|}{ Translation Strategy } & \multicolumn{3}{|c|}{ Equivalence Level } \\
\cline { 3 - 5 } & Accurate & $\begin{array}{c}\text { Less- } \\
\text { accurate }\end{array}$ & Inaccurate \\
\hline 1 & $\begin{array}{l}\text { Translation by Using Idiom in } \\
\text { Similar Meaning and Similar } \\
\text { Form }\end{array}$ & 0 & 0 & 0 \\
\hline 2 & $\begin{array}{l}\text { Translation by Using Idiom in } \\
\text { Similar Meaning but Disimilar } \\
\text { Form }\end{array}$ & 4 & 0 & 0 \\
\hline 3 & Translation by Paraphrase & 32 & 4 & 10 \\
\hline 4 & Translation by Omission & 0 & 0 & 1 \\
\hline
\end{tabular}

There is no idiom translated by using translation by using idiom in similar meaning and similar form strategy. The meaning of 4 idioms were accurately translated by using translation by using idiom in similar meaning but disimilar form strategy. In paraphrased strategy, meaning of 32 idioms were regarded as accurate, meaning of 4 idioms were regarded as less-accurate, and the meaning of 10 idioms was inaccurate. The last, the meaning of 1 idiom found as inaccurate translation by using omission strategy.

\section{Discussion}

Discussion of Translation Strategy

\section{- Translation by Using Idiom in Similar Meaning but Disimilar Form}

According to Baker (2006), because there are many idioms in the SL that have similarity meaning (expression) with the idiom in the TL, but different in the form, in this case lexical item, it is allowed to used this strategy as long as both SL and TL are expressed the same, although in different form. From the data, idiom hang out was translated into 'nongkrong'. It can be concluded that, 
although the word 'nongkrong' has different different form from the SL which is nongkrong is not an idiom, but this the word nongkrong doesn't refer to sitting, but its meaning is spending time to gather with friends (KBBI). In conclusion, 'nongkrong' is not idiom, but it cannot be translated literally as the action of sitting. The next example of idiom is make some noise and its translation bersorak. Make some noise means speak or act in a way designed to attract a lot of attention or to cheer someone (Oxford Dictionary Idiom, 2004: 201). Although bersorak is not an idiom (or has different lexical item), but bersorak in this movie also means to cheer someone (KBBI online). It can be concluded that make some noise and bersorak are expressed the same.

\section{- Translation by Paraphrase}

This is by far the most common way of translating idioms when a match cannot be found in the target language or when it seems inappropriate to use idiomatic language in the target text because of differences in stylistics preferences of the source and target languages (Baker, 2006: 71-77). This strategy is allowed as long as the translation in the TL is refer the meaning of idiom in the SL. From the finding of analysis, this strategy takes the higher frequency (46) of usage by the translator (Arythoon), The translator used this strategy because he found the right equivalent of the idiom using a single or group of words that roughly suitable to the meaning of that idiom. As seen in (SL) 'what's up, Pitches?', the words what's up in this sentence means greeting or saying hallo in informal (NTC's American Idioms Dictionary, 2000: 432). The translation of this sentence is 'Apa kabar, Pitches?'. The words apa kabar is commonly used in Indonesia when someone wants to greet the other. 
On the sentence 'You take good care of my Turnip Top', take good care is idiom. This idiom means to handle or manage someone or something or to provide care for someone or something (NTC's American Idioms Dictionary, 2000: 391). The translator paraphrased this idiom into rawatlah. This translation is allowed because the word rawatlah is refer to the meaning of take good care in Indonesia. The other translated idiom by using this strategy on this movie is split up and its translation berpencar. The words split up means to separate or leave one another (NTC's American Idiom, 2000: 374). Berpencar is the correct translation, because berpencar in Indonesia refers to the meaning of split up. The last is handful, this idiom is used to expressed something or someone that is difficult to manage (NTC's American Idiom Dictionary, 2000: 172). The translator paraphrased this idiom into merepotkan. Although the word merepotkan is not idiom or has the other meaning in Indonesia, this translation is allowed. And the word merepotkan is always used when someone thinks that person, job, or etc is difficult to manage by him/her in Indonesia.

From the explanation above, translation by paraphrase is used to minimize misunderstanding of the readers, to make readers easily understanding the intention of the message from the SL, also to make the translation as natural as possible.

\section{- Translation by Omission}

The last strategy is Translation by Omission. One idiom was translated by this strategy according to the data. This strategy is used when there is no close match of the idiom in the TL, or the idiom in SL meaning is hard to be paraphrased. As long as this is not change all the context of the message, this strategy is allowed. According to the analysis, the translator used this strategy in translating idiom in 
sentence 'I just figured out what he reminds me of'. The words figure out is omit in the TL 'dia tiba-tiba mengingatkanku'.

\section{Discussion of the Translation Equivalence Level.}

To decide where is the idiom that translate accurately or not, the researcher used the meaning of idiom (in SL) by using idiom dictionary. By looking the meaning, the researcher will knowing the idiom is correctly translate or not. To determine which idioms were translated accurate, less-accurate, or inaccurate, the researcher used the criteria of accurately translation by Nababan (2012).

\section{- Accurate Translation}

When the meaning is well translated, which mean there is no addition or substruction of information that is not equivalence with the SL, this translation is an accurate translation (Nababan, 2012). According to the finding, 36 of 51 idioms were classified as the accurate translation. It means, the translation of idioms in the Indonesian subtitle were appropriate delivered or equal with the meaning of the idioms in English subtitle. This stated is according to Rahimi (2004), which stated that when the suitable and detailed explanation of the source message and the transmission of that message as exactly as possible.

The first is Translation by using idiom in similar meaning and similar form strategy. As was stated before, the translator did not used this strategy in translating idiom on his subtitle.

The second is Translation by using idiom in similar meaning but disimilar form. 4 idioms were found as accurately translated by using this strategy. It means, all idioms that translated by used this strategy are accurate translation. For example Make some noise. This idiom is translated into bersorak. Make some noise means is speak or act in a way designed to attract a lot of attention or to cheer someone 
(Oxford Dictionary Idiom, 2004: 201) and bersorak, although is not an idiom (or has different lexical item), but bersorak is word that used to cheer someone (KBBI online). From the explanation, both make some noise and bersorak is a accurately translation because its expressed the same meaning. The other translation accurately by using this strategy is take in that was translated into dicerna. Take in in this movie means to absorb and comprehend the some informations (NTC's American Idiom Dictionary, 2000: 390). Dicerna on this case, its not dicerna that refer to digest food but refer to process the information. So, take in and dicerna is accurate translation.

The third strategy is translation by paraphrase which has 32 idioms that translated accurate. In the sentence of the source subtitle "He got over you much quicker than what I thought", idiom got over means to recover someone (NTC's American Idiom Dictionary: 142), and the translator translated it into melupakanmu. Melupakan is the word that roughly suitable to the meaning of got over and also always used by people in Indonesia. The other is kicked out. Kicked out means to send someone away from a place (NTC's American Idiom Dictionary: 233). The translator is accurate translated it into diusir, because diusir is confirmed the meaning of kicked out in Bahasa. More accurate translation is idiom in "So, put your hands together for the Bellas". Put your hands together is means giving applaud (NTC's American Idiom Dictionary: 326). Giving applaud in Indonesia is tepuk tangan, and the translator translated the idiom into tepuk tangan. Which means this translation is accurate.

The last sample is idiom let you down which has meaning to make someone dissapointed (Idioms-freedictionary.com), and its translation mengecewakanmu. This is accurate translation because mengecewakanmu is confirmed the meaning of let you down in Bahasa. The translator is accurate translate by using this 
strategy when he/she is able to translate the idiom by using a group of words or a single word, which confirmed the meaning of idiom to the TL.

And the last, there is no idioms that translated accurately by using translation by omission strategy. It can be concluded that, the paraphrase strategy has the huge accurately data that translated.

\section{- Less Accurate Translation}

The less accurately translation occurs when there is a disortion of meaning or translation of double meaning (ambiguous) or half existing meaning is eliminated, which interrupt the integrity of the message. From the table 2, only one strategy that has less accurately idiom translation, it was translation by paraphrase. It occurs 4 idiom that was translated less accurate. For example idiom in the data from SL "It's just too bad that he can't make it". Make it here means to succed or to achieve one goal. The translator translated it into melakukannya. Melakukannya in here is not wrong translation, but it is also not accurate. It is because the word melakukannya not confirmed all the meaning of make it. Maybe if the translator changes it into mewujudkannya, the translation maybe accurate. The translator also translates idiom in phrase "Amy, come on! Amy!" into "Amy, ayolah! Amy" as less-accurate translation. It is because come on! in here means to hurry up (NTC's American Idiom Dictionary: 74), and the word ayolah! does not show the most important part of come on! meaning, it is not represent the term hurry. Supposedly, the translator change it to the word cepatlah! to make the sentence really show that someone is asked the other to move quickly.

\section{- Inaccurate Translation}

The inaccurate translation occurs when the meaning of the word, a technical term, phrase, clause, sentence or source language text uncorrectly transferred into the 
target language or omitted, so the message of the source language is not fully translated (Nababan, 2011). It means, this happens when the translator failed to convey the meaning from SL to TL, so the meaning of idiom is not delivered in the TL. From table 2, There are 11 idioms that had been found as inaccurate translation. There is no idiom inaccurate translation found in translation by using idiom in similar meaning and similar form strategy and translation by using idiom in similar meaning but disimilar form strategy.

From the table 3, there are 10 idioms were found as inaccurate translation in using translation by paraphrase. Idiom cool beans was translated as kacangnya dingin in the TL. It was clearly wrong because the meaning of cool beans is to express something amazing; or great (NCT's American Idiom Dictionary: 78), but the translator translated it as literarly as kacangnya dingin. Same as in idiom sit tight. Sit tight means to wait patiently without taking any immediate action (NCT's American Idiom Dictionary: 365). But, the translator translated it into duduklah. It is clearly wrong, because sit tight in here doesn't refer to sitting. the translation is inaccurate translation. Sit tight in here should be translated into tenanglah. The other idiom in the TL is child's play. Child's play means something very easy to do (Idiom-freedictionary.com). The translator translated this idiom into mainannya. This is clearly inaccurate translation because the word mainannya doesn't confirm the meaning of child's play. So, it makes the translation is inaccurate. The word child's play should be translated as sangat mudah or mudah.

The last is the inaccurate translation by using translation by omission. 1 idiom translated by using this strategy was inaccurate. Although the translation by using this is allowed when the translators does't find the equivalence idiom in the TL, but, from the finding, the researcher found why the idiom translation are inaccurate. There is idiom figured out that has meaning to find an explanation for 
someone or something (NTC's American Idiom Dictionary: 115), which mean, in the TL, the translation should be kira-kira, but the translators omitted the idiom from the sentence. Moreover, Larson (1998) stated that the inaccurate translation is because omission of some parts which existed in the original text. Although omission in this strategy is provided and allowed but several requirements must be fulfilled. The translator should not reduce the message of the idiom from SLT.

\section{CONCLUSION AND SUGGESTION}

\section{Conclusion}

The aims of this research is to describe how the translators translate idioms from English into Indonesia in the Pitch Perfect 3 movie. Concerning to the translation strategy used, the translator applied 3 strategies to make the subtitle. Those strategies are translation by using idiom in similar meaning but disimalr form, translation by paraphrase, and translation by omission. The translator is able to use translation by using idiom in similar meaning but disimilar form and translation by paraphrase strategy. It can be seen by all the idioms that were translated by using idiom in similar meaning but disimilar form were accurately translation and the large number of accurate translation by using paraphrase. The translator failed to translate idiom by using omission strategy. The only idiom that translated by this strategy was classified as the inaccurate translation.

\section{Suggestion}

From the conclusion, the researcher would like to give some suggestions for the further researcher to analyze the other aspect that can appear in the movie or novel, such as collocation, direct-indirect speech, speech act, or etc. The further researcher can analyze the Readability and Acceptability of the translation product. 


\section{E. REFERENCES}

Carrie Williams. 2007. Research Methods. Journal of Business \& Economic Research. Vol. 5, No.3, p 69

Mangatur Nababan, Ardiana Nuraeni \& Sumardiono. 2012. Pengembangan Model Penilaian Kualitas Terjemahan. Kajian Linguistik dan Sastra, Vol. 24, No. 1: 3957

Rahimi, R. (2004). Alpha, beta and gamma features in translation: Towards the objectivity of testing translation, Translation Studies, (2)5, Pages 53-64.

Baker, Mona. 2006. In Other Words: A Course Book on Translation. London \& New York: Routledge.

Fraenkel, Jack\& Norman Wallen. 2010. How to Design and Evaluate Research in Education 7th edition. New York: McGraw-Hill.

Hatim, Basil and Ian Mason. 1997. The Translator as Communicator. London and New York: Routledge.

Larson, Mildred. 1998. Meaning Based Translation: A Guide to Cross Language Equivalent $2^{\text {nd }}$ Edition. Lanham, MD: University Press of America, Inc,

Newmark, Peter. 1988. A Textbook of Translation. New York: Prentice Hall.

Sugiyono. 2008. Metode Penelitian Kuantitatif, Kualitatif R\&D. Bandung: Alfabet.

Kamus Besar Bahasa Indonesia (KBBI) Online. (2019). Retrieved from http://kbbi.web.id/

Oxford Dictionary of Idioms 2nd Edition. New York: Oxford University Press Inc, 2004.

Richard A. Spears, Ph.D. 2000. NTC'S American IDIOMS Dictionary 3rd edition. The McGraw-Hill Companies: USA)

www.idiom-freedictionary.com 